\title{
OBITUARY
}

\section{MARMADUKE STEPHEN MAYOU}

IT was with deep regret that we briefly recorded last month the death of Stephen Mayou on July 20. By this untimely event, the Ophthalmological Society has lost its President, and ophthalmology in general, one of its most outstanding men.

Marmaduke Stephen Mayou was born at Monmouth, in May, 1876 , and came of a medical family, his father being George Mayou, M.D. His medical education was received at King's College, and the London Hospitals, as a student he won the Warneford Scholarship and Jelf Medal. He qualified M.R.C.S., L.R.C.P. at the early age of 21 years, and four years later obtained the F.R.C.S. England, thus laying the foundation of a brilliant scientific career.

Though Mayou's activities in ophthalmology were of the widest, he probably will be remembered best for his work on the conjunctiva. His interest in this subject was shown early in his career, and in 1904 he was awarded the Jacksonian prize for his essay on "Conjunctivitis: Its Pathology, Varieties and Treatment." In 1905 he held the Hunterian Professorship of the Royal College of Surgeons, taking as the subject of his lecture "The Changes Produced by Inflammation in the Conjunctiva;" while in 1918, when the London County Council decided to establish St. Margaret's Hospital for the treatment of ophthalmia neonatorum; he was appointed as its Consulting Surgeon. The work he did here was of incalculable value; from the point of view of treating the patients, of teaching the medical students and midwives who attended for training, and of establishing the fact that with proper care and precautions, an attack of ophthalmia neonatorum need not cause any permanent impairment of vision.

Somewhat similar in nature was his work at White Oak, where, in 1927, he followed the late $\mathrm{Mr}$. Treacher Collins as Visiting Ophthalmic Surgeon. This hospital, primarily founded for the treatment of trachoma, was also used in later years for cases of interstitial keratitis, chronic conjunctival and corneal disease, and abundantly justified its purpose.

Mayou's work was not limited to the conjunctiva, and he realised early in his career the important part that a proper understanding of pathology plays in the education of an ophthalmologist.

Most men would have been satisfied, when thev obtained the post of pathologist and radiographer to an eve hospital, to have published a few desultory papers on the specimens which came their way, but this was not the case with Mayou. His zeal and 


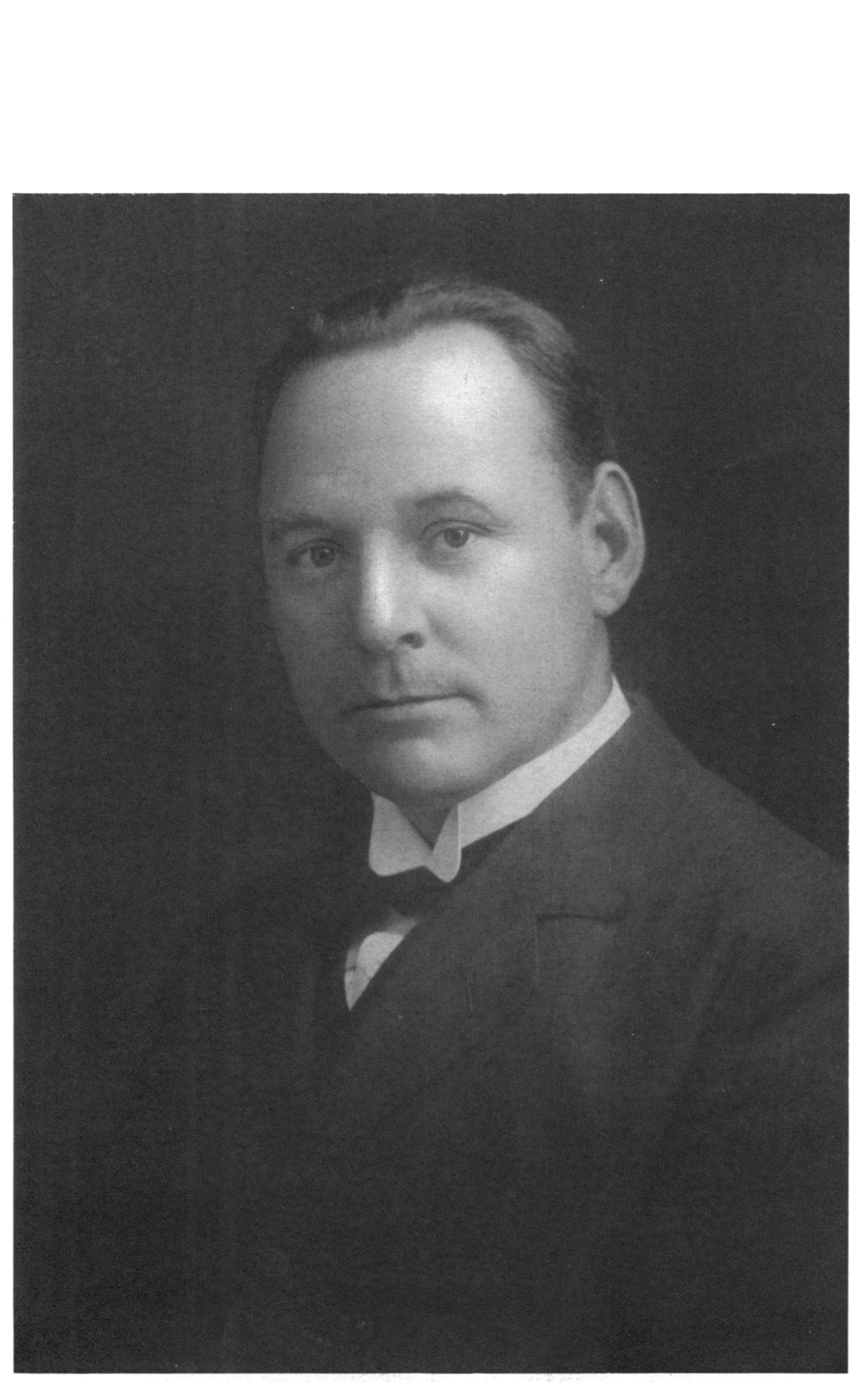

MARMADUKE STEPHEN MAYOU-1876-1934 
energy led him in 1911 to produce, in collaboration with Treacher Collins, a much valued book on the pathology and bacteriology of the eye, which is familiar to all English speaking ophthalmologists. A second enlarged edition of this work was published in 1924.

Mayou also catered for the undergraduate student of ophthalmology, and the small handbook he wrote on diseases of the eye, obtained a well deserved popularity and is now in its fourth edition. In preparing this volume, he had a wealth of clinical material on which to draw, for, in addition to holding the post of Senior Surgeon to the Central London Ophthalmic Hospital, he was also Ophthalmic Surgeon to the Bolingbroke Hospital at Wandsworth.

Almost every branch of human ophthalmology was covered by his writings, but even this did not exhaust Mayou's capacity for work, and quite recently there appeared in this journal, an article from his pen, on the subject of retinal visual cells in man and freshwater fish.

Those who were privileged to work with Mayou at the Central London Ophthalmic Hospital will realise what the untiring devotion of one man can mean to an institution. He took the keenest interest in all phases of its development, and it was due to his initiative that the hospital possesses a remarkably fine set of private wards under the name of the Princess Marie Louise Wing. Every item of their equipment, furniture and design was a matter of personal interest to him, and the same is true of the recently completed squint training department.

Mayou's association with this journal was a close one, he contributed many articles to its pages and up to his death was a member of its editorial and executive committee. He served also on another executive committee, namely that of the Council of British Ophthalmologists, of which he was Honorary Treasurer. His presence here was valuable especially as a liaison officer between that body and the British Medical Association, since he had represented the latter in 1930 on the National Ophthalmic Treatment Board. He served also on the Council of the Section of Ophthalmology of the Royal Society of Medicine and was an original member of the Section.

Mayou was a well known figure in Masonry. He was Master of the Captain Coram Lodge and ophthalmic surgeon to the Royal Masonic Hospital, and to the Masonic schools at Weybridge and at Clapham Junction.

In 1933 he was accorded by his fellows the coveted distinction of being elected President of the Ophthalmological Society of the United Kingdom. He was to have held this office for two years and had already done valuable service to the Society when death cut short his career. 
That one man should have held so many posts was an undoubted tribute to his character. In committee, his opinions were always definite and founded on sound reason. Should he decide on a course of action, none knew better than he how to carry it through, and with a happy smile on his face, he was always ready to tell his colleagues the right mode of procedure. He had a wonderful knowledge of human nature, and it was this, coupled with his native charm, which made Mayou such a valuable member of any committee. Although he could usually see further than most people, if his views were not accepted, he was quite unruffled and would stand by the decision of his colleagues.

In private practice, he had a host of patients by whom he was regarded with gratitude, esteem and confidence. His profound knowledge and experience were at their service, and his skill in operating was of a high order.

Away from his work, Mayou had many hobbies. He was a keen horticulturist and fisherman and an expert golfer. His country house at Camberley was near the links, and his kind hospitality to those taking part in the ophthalmic inter-hospital golf matches, will be an ever-green memory to those who played in them. As Captain of the Central London Ophthalmic Hospital team he frequently led his side to victory.

No account of Mayou would be complete without an allusion to the valiant fight he put up against ill health during the last five years of his life. Though physically a sick man, his zeal and energy were such that he completely conquered his disabilities. In the intervals between attacks, his zest for work, sport and hospital organization was untiring, and no one meeting him would have realized his handicap.

He was a most genial and generous host, full of humour mixed with a kindly cynicism; a man one respected and loved, but never feared. He had great understanding of human nature, but little patience with inefficiency.

In all his activities, Mayou was staunchly supported by his wife, whose initiative, strength of character and encouragement were of supreme importance in helping him to the achievement of his ambitions. To her and to his three daughters, we extend our deepest sympathy. 